\title{
Implementation of a student-centered approach in blended learning in a higher educational institution
}

\author{
Zh V Smirnova ${ }^{l}, O I$ Vaganova $^{l}, E A$ Eltanskaya $^{2}, V G$ Lizunkov $^{3}, L K$ Parsieva $^{4}$ \\ ${ }^{1}$ Minin Nizhny Novgorod State Pedagogical University, 9, Chelyuskin str., 603004, Nizhny Novgorod, Russia \\ ${ }^{2}$ Volgograd State University, 100, Universitetsky ave., 400062, Volgograd, Russia \\ ${ }^{3}$ Yurga Institute of Technology (Branch) of National Research Tomsk Polytechnic University, Department of Digital Technology, 36, \\ Lenin Ave., 634050,Tomsk, Russia \\ ${ }^{4}$ North Ossetian State University, 44-46, Vatutina street, 362025, Vladikavkaz, Russia
}

\begin{abstract}
The competence approach and e-learning have changed the role of the teacher in the student's life. In the article, the authors reveal the essence and features of this type of training (mixed). The authors consider the development of a student-centred approach. It is noted that working with the whole group, the teacher organizes the work of each, creating the conditions for the development of students' personal opportunities. Since with the entry into force of the new requirements of the Federal state educational standards, a qualitatively new relationship between the student and the teacher has appeared, the identification of their features and the determination of their role in the educational process have become particularly relevant. The article pays attention to the model of the teacher's activity within the framework of student-centred education and its main elements are noted. The authors identified features of blended learning and tools of electronic platforms that support the development of subject-subject relations between students and teachers. The authors emphasize the need to ensure equal starting conditions for the study of the discipline as a whole and suggest principles that should be followed when implementing the studentcentred approach within the framework of blended learning.
\end{abstract}

\section{Introduction}

The reform of higher education has had a large-scale impact not only on the construction of the learning process itself in higher schools, but also on its very essence. Many scholars pointed out these transformations which gave rise to a new goal of preparing students, which we will discuss below. Developing the question of innovations, we should start with the requirements of the Federal State Educational Standards [1]. As soon as they entered into force, a competence educational paradigm appeared in the higher education of the Russian Federation [2]. Now the training of students is more independent.

Traditional training of students, undoubtedly, brought good results for many years, but its purpose (the transfer to students of a certain amount of knowledge and skills) no longer corresponded to the modern needs of the state and society. A graduate with a high level of theoretical training could not quickly cope with the solution of a practical problem $[3,4,5]$. Therefore, the state decided to introduce new provisions on education [6]. It led to the emergence of the competence-based approach, the purpose of which is to develop students' competencies so that that future graduates can apply them independently in practice [7]. The competence approach was addressed by such researchers as E.A. Bystrov, I.A.
Winter, A.A. Leonov, L.A. Petrovskaya. Among foreign scientists, this issue was studied by J. Raven, R. Merton, R. White [8].

Federal state educational standards of a new generation have also introduced requirements for the use of e-learning $[9,10]$. Competence and e-learning have led to a new type of relationship between teachers and students. The role of the teacher in the student's life has changed radically [11]. Now he is not a transmitter of knowledge, but a tutor accompanying students in the classroom [12]. Thanks to these trends, a mixed type of training has emerged [13]. Within its framework, both students and teachers act in a completely different way. Despite the great attention of scientists to this topic, it remains insufficiently studied. The relevance of the article is to identify new features in the implementation of the student-centered approach in vocational education in blended learning.

\section{Methodology}

The analysis of the experience of applying the studentcentered approach allowed a deep study of the issue of its development and application in higher educational institutions as part of blended learning. We studied literature on the issue of blended learning and the

* Corresponding author: z.v.smirnova@mininuniver.ru 
subject-subject relationship between students and teachers. By analyzing the given information and synthesizing the identified characteristics of studentcentered learning, the main points of the research were formulated.

\section{Results and discussions}

Within the framework of the new educational paradigm, as we have already mentioned, the relationship between the teacher and the student has changed and acquired qualitatively new characteristics. These relationships are considered in the framework of the student-centered approach [14].

The goal of learner-centered learning is to maximize the development of the individual abilities of the learner through the use of his experience (treating the student as an individual, as a self-conscious responsible subject of their own development [15]. The personality-oriented approach allows the student to identify and discover their potential through self-awareness development. Personal realization is significant. Socially approved motives of self-realization and self-affirmation should be taken into consideration [16].

The model of teacher activity in the framework of the student-centered approach should have the following elements:

- goal setting (goal: the creation of such conditions in which the student becomes an active subject of cognitive activity; in the lesson a constant dialogue is organized between the teacher and the student) [17];

- the activity of the teacher (relying on joint work with the teacher, the student carries out an independent search for information; the teacher guides the learner to achieve the goal) [18];

- student's activity (student - a subject of pedagogical activity, the initiative for solving the problem comes from the student himself; methods of problem-searching and project training are used) [19];

- subject-subject interaction between the student and the teacher (working with the whole group, the teacher organizes the work of each, creating conditions for the development of students' personal capabilities, including the formation of reflective thinking and their own opinions) [20].

The educational model is based on the following principles:

- training is aimed at personal development. The teacher and the student are equal subjects of education [21];

- the teacher is a partner, coordinator and adviser in the learning process and only then he acts as a leader [22].

To implement a student-centered approach within the blended learning framework, it is necessary to ensure equal starting conditions for studying the discipline as a whole.

We emphasize that blended learning is the most favorable condition for the development of subjectsubject relations between students and teachers. The teacher selects the necessary content in accordance with the level of training of students or uses authoring, applying multimedia content. The teacher, through his actions, directs students, influences them, encouraging them to develop themselves. Constant online access to ecourse tools increases student engagement and thus ensures his active participation in training [23].

The educational process in blended learning is lined up with alternation of traditional and electronic types of learning $[24,25,26]$. Initially, the teacher should prepare students with the help of special information letters, consultations, conducting in-person briefings and a brief overview of the course using video materials [27,28,29]. Further, he conducts conceptual presentations to the audience, demonstrates virtual seminars and examplebased learning [30,31].

Conducting work in electronic form, the teacher has the opportunity to implement the student-centered approach through the tools of various electronic platforms [32]. Often, higher education institutions use Moodle for this purpose because of their openness, free of charge, and convenient management system. Wiki, forum, chat and personal messages allow the student to contact the teacher and get timely advice on any issue. Figure 1 shows the chat placed in Moodle that the teacher offers his students to use.

In this chat in on-lain mode you can ask additional questions.

Figure 1 Chat on Moodle platform.

These tools also allow the teacher to make the student pay attention to gaps in knowledge in time. The teacher points to topics that should be given more attention and the student himself obtains the necessary information on these issues, having the opportunity to always ask for help.

It is necessary to note that humanitarian and technical areas of training have their own characteristics. Training future engineers is a long and multi-faceted process where it is extremely important to pay attention to each topic. Competitiveness of future professionals depends on it. In blended learning, the teacher should prepare his e-course especially carefully and, if possible, provide feedback not only through chat rooms, but also video conferences. It is often easier for a student to formulate his question under such conditions. So, the teacher will be able to quickly help the student build his educational path.

It is advisable to emphasize the requirements that must be met in the context of the student-centered approach in blended learning:

- at the stage of results formulation, it is necessary to plan adequate control methods and assessment tools;

- a clear definition of learning outcomes;

- development of positive perception of modern test options by students. 


\section{Conclusions}

We reviewed the implementation of the student-centered approach to blended learning in higher education institutions. The study is carried out with the grant support for young scientists - candidates of sciences, number MK-313.2019.6, issued by the President of the Russian Federation. We found that the use of this approach gives students great advantages since the educational process in such conditions acquires flexibility and openness. Students have the opportunity to choose the pace, rhythm and amount of educational material necessary for mastering on an individual basis. Many high schools choose Moodle for providing blended learning. These tools contribute to the development of subject-subject interaction (partnerships) between students and teachers. From the passive consumer of ready-made knowledge, the student becomes an active independent participant in educational process becoming responsible for the results of his own activities.

\section{Acknowledgement}

The study was carried out with the grant support for young scientists - candidates of sciences, number MK313.2019.6, issued by the President of the Russian Federation.

\section{References}

1. M.N. Bulaeva, O.I. Vaganova, M.N. Gladkova, Baltic Humanitarian Journal Activity technologies in a professional educational institution, 7 (3(24)), 167170 (2018), Retrieved from: https://elibrary.ru/item.asp?id=36237878

2. O.I. Vaganova, A.V. Gladkov, A.V. Trutanova, , Baltic Humanitarian Journal Formation of professional competencies of bachelors in the conditions of e-learning 6 (2(19)), 190-193 (2017), Retrieved

from: https://elibrary.ru/item.asp?id=29415561

3. O.I. Vaganova, L.K. Ilyashenko, Vesknik of Minin University The main directions of implementation technologies of student-centered education in high school, 6 (3), 2 (2018), DOI: 10.26795/2307-12812018-6-3-2

4. O.I. Vaganova, M.I. Koldina, A.V. Trutanova, Baltic Humanitarian Journal Development of the content of vocational and pedagogical education in the context of implementation of the competence approach, 6 (2(19)), 97-99 (2017).

5. E. Malushko, O. Maletina, V. Tsybaneva, Advances in Social Science Education and Humanities Research (ASSEHR) Teaching Discussion Skills As Part Of Further Teachers' Training, , 97, 175-180 (2017)

6. E.P. Garina, A.P. Garin, V.P. Kuznetsov, E.G. Popkova, Y.S. Potashnik, Advances in Intelligent Systems and Computing, Comparison of approaches to development of industrial production in the context of the development of a complex product, 622, 422431 (2018), DOI: 10.1007/978-3-319-75383-6_54

7. L.K. Ilyashenko, M.P. Prokhorova, O.I. Vaganova, Z.V. Smirnova, E.A. Aleshugina, IJMET, Managerial preparation of engineers with eyes of students, 9(4), 1080-1087 (April 2018).

8. L.K. Ilyashenko, Z.V. Smirnova, O.I. Vaganova, M.P. Prokhorova, N.S. Abramova, International Journal of Mechanical Engineering and Technology, The role of network interaction in the professional training of future engineers, 9 (4), 1097-1105 (2018).

9. L.K. Ilyashenko, O.I. Vaganova, Z.V. Smirnova, M.L. Gruzdeva, A.V. Chanchina, International Journal of Mechanical Engineering and Technology Structure and content of the electronic schoolmethodical complex on the discipline "mechanics of soils, foundations and foundations", 9 (4), 1088-1096 (2018).

10. L.K. Ilyashenko, O.I. Vaganova, Z.V. Smirnova, E.P. Sedykh, O.G. Shagalova,, International Journal of Mechanical Engineering and Technology Implementation of heurist training technology in the formation of future engineers 9 (4), 1029-1035 (2018).

11. Svetlana S. Ivanova, Elena V. Bystritskaya, Irina Y. Burkhanova, et al., Eurasian journal of analytical chemistry Physical Culture Teacher Professional Activity Problems in Polyethnic Educational Organization, 12(7B), 1615-1620 (2017).

12. E. V. Kochetova, E. G. Gutsu, N. N. Demeneva, et al., Journal of fundamental and applied sciences Psychological mechanisms of future pedagogues' professional individualization formation during their studies in a higher educational institution, 9(SI), Supplement: 2, 1484-1493 (2017).

13. S.M. Markova, A.K. Narcosiev, Vestnik of Minin University Professional education of vocational school students, 6(3), 3 (2018), DOI: 10.26795/23071281-2018-6-3-3.

14. E.V. Myalkina, E.P. Sedhyh, V.A. Zhitkova, V.A. Vaskina, O.I. Isaykov, Vestnik of Minin University University resource center as an element of social development of the region, 6(3), 1 (2018), DOI: 10.26795/2307-1281-2018-6-3-1.

15. M.A. Suzdalova, V.G. Lizunkov, E.Yu. Malushko, N.A. Sytina, V.E. Medvedev, EpSBS, Innovative Forms of Partnership in Development and Implementation of University-Business Cooperation, XIX, 450-455 (2017).

16. F. Nikolai, I. Kobylin, LOGOS American trauma studies and the limits of their transitivity in Russia heart-to-heart talks with veterans of local conflicts, 5, 115-136 (2017).

17. A. Pavlov, A. Kindaev, I. Vinnikova, E. Kuznetsova, International Journal of Environmental and Science Education Crop insurance as a means of increasing efficiency of agricultural production in Russia, 11(18), 11863-11868 (2016). 
18. T. V. Perova, E. A. Kuznetsova, I. S. Vinnikova, S. N. Kaznacheeva, E. A. Chelnokova, International Journal of Applied Business and Economic Research, Essence of the role and characteristics of the operating conditions of enterprises before and after the transition to market relations from a macroeconomic position, 15(12), 103-112 (2017).

19. M.P. Prokhorova, A.A. Semchenko, Vestnik of Minin University Involving of trainees-future teachers of professional training in project activities in the discipline, 6(2), 6 (2018), DOI: 10.26795/2307-1281-2018-6-2-6.

20. A.A. Skatova, D. S. Yambulatov, I. L. Fedyushkin, et al., Russian Journal of coordination chemistry Europium and Ytterbium Complexes with the Redox Active Acenaphthene-1,2-Diimine Ligand, 44(6), 400-409 (JUN 2018).

21. ZH.V. Smirnova, M.L. Gruzdeva, O.G. Krasikova, Vesknik of Minin University Open electronic courses in the educational activities of the university, 4(21), 3 (2017), DOI: https://doi.org/10.26795/23071281-2018-6-3-9.

22. Zh.V. Smirnova, O.G. Krasikova, Vestnik of Minin University Modern tools and technologies for assessing learning outcomes, 6(3), 9 (2018), DOI: 10.26795/2307-1281-2018-6-3-9.

23. ZH.V. Smirnova, O.I. Vaganova, A.V. Trutanova, Karelian Scientific Journal Final state certification as a way to comprehensive assessment of competences, 6 (3(20)), $74-77$ (2017), Retrieved from: https://elibrary.ru/item.asp?id=30453035 (date of access: 16.03.17).

24. S. M. Hamitowa, A. P. Glinushkin, Y. M. Avdeev, et al., International journal of pharmaceutical research and allied sciences Condition Assessment of Tree Plantations and Phytosanitary Properties of Soils in Cedar Groves, 6(4), 1-7 (2017).

25.Z.V. Chaikina, S.M. Shevchenko, M.V. Mukhina, O.V. Katkova, L.I. Kutepova, The Impact of Information on Modern Humans Popkova E.G. (ed.), Springer, Electronic testing as a tool for optimizing the process of control over the results of educational training activities, 622, 194-200 (2018), DOI: https://doi.org/10.1007/978-3-319-75383-6_25

26. E. Malushko, O. Maletina, V. Lizunkov, V. Tsybaneva, International Multidisciplinary Scientific Conferences on Social Sciences and Arts, Use of virtual learning system for educating students with disabilities and special needs, 481-487 (2016).

27. E. Korobova, I. Kardovich, D. Mironova, M. Konysheva, ASSEHR Dependence of approaches and methods of foreign language teaching on socioeconomic factors, 97, 119-124 (2017).

28. E.V. Murugova, Vestnik Volgogradskogo Gosudarstvennogo Universiteta-seriya 2yazykoznanie, Theoretical and applied aspects of corpus-based researches, 16 (2), 197-200 (2017).

29. D.Yu. Gulinov, M.R. Zheltukhina, L.A. Shestak, G.G. Slyshkin, V.V. Katermina, L.D. Chervyakova. Modern Journal of Language Teaching Methods, Modern Language Policy: Specifics of Formation and Development of the French Vertical. 8 (2), 159173 (2018).

30. Natalie V. Kamenez, Zhanna V. Smirnova, Olga I. Vaganova, Natalia V. Bystrova and Julia M. Tsarapkina, International Journal of Mechanical Engineering and Technology, Development of Instructing Techniques in Professional Training, 10(02), 2019, 899-907

31. Lubov K. Ilyashenko, Zhanna V. Smirnova, Olga I. Vaganova, Elena A. Chelnokova and Svetlana N. Kaznacheeva, International Journal of Mechanical Engineering and Technology, Methods of Conducting Practical Training on the Subject "Power Sources for Welding", 10(02), 2019, 908-917

32. Vaganova, O. I., Smirnova, Zh. V., Markova, S. M., Chaikina, Zh. V., \& Bulaeva, M. N. (2019). Perspektivy nauki i obrazovania - Perspectives of Science and Education, Organization of partnerships for additional educational services on the example of the interaction of the educational institution with the health and cultural centre. 39 (3), 500-514. doi: 10.32744/pse.2019.3.38 